А. В. Макеенкова

\title{
Феномены «классического» и «современного» в истории изобразительного искусства
}

Аннотация: остро стоящей перед искусствознанием проблемы «начала истории искусства» сегодня нет, в то время как его текущее состояние вызывает множество вопросов. Сложность изучения современного искусства обусловлена тем, что его формы крайне многообразны. Поэтому автор предлагает обобщить это явление под понятием «модернизм». Оно вбирает в себя все направления современного искусства, начиная с импрессионистов, а также указывает на общность процессов, которые начались в искусстве в последней четверти XIX в. и продолжаются до настоящего времени. До сих пор главной интригой науки об искусстве остается появление модернизма, всколыхнувшего старую тему «смерти искусства»: «Черный квадрат» К. С. Малевича трактуется как надгробный памятник классического искусства. Но «классическое» в искусстве не есть что-то устойчивое и постоянное. Модернизм не «убивал» классическое искусство, оно медленно вырождалось по мере потери в нем действительной необходимости.

Ключевъе слова: искусствоведение, история искусства, классическое искусство, современное искусство, кризис искусства, модернизм, авангард, постмодернизм, стиль, реализм.

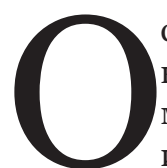
сновой, на которой было воздвигнуто здание истории искусства, является трансформация художественных форм во времени: их взаимовлияние, взаимопроникновение и, конечно же, взаимоотторжение. Оставайся искусство неизменным, оно не ставилось бы исследователями как проблема и совершенно не нуждалось в изучении. Таким образом, проблема генезиса, взаимопроникновения и оппозиции художественных стилей для науки об искусстве ключевая.

Остро стоящей перед искусствознанием проблемы «начала истории искусства» сегодня нет, в то время как его текущее состояние вызывает множество вопросов. До сих пор главной интригой науки об искусстве остается появление модернизма, всколыхнувшего старую тему «смерти искусства». Комплекс связанных с этим осложнений выходит за пределы искусствознания и стоит перед нами как философская проблема. Одна из ведущих задач искусствознания - осмысление причин ухода на второй план «классических» форм и выдвижения «современного» искусства. Но в гуманитарных науках нет бесспорных терминов, и каждое понятие с момента возникновения несет весомый багаж проблематики. Обращение к истории этих терминов, даже если и не позволит нам разрешить проблемы искусствознания, то расставит акценты таким образом, чтобы облегчить изучение современного искусства будущим исследователям.

Признаком классического искусства является искусное повторение природных форм, которые идеализируются; искусство внушает зрителю, что человек находится в центре мироздания, чему способствуют правила прямой перспективы. Но, если непредвзято посмотреть на историю искус- ства, можно сделать вывод, что периоды классики и всех разновидностей классицизмов будут короткими вспышками на фоне многообразия европейских художественных стилей. Поэтому нарастание антиклассических тенденций, которые были «новыми» по отношению к академизму XIX в., - всего лишь один из эпизодов истории искусства.

Строго говоря, классическим мы называем краткий (охватывающий не более двух веков) период в истории древнегреческого искусства, появлению которого предшествовали многие столетия существования не менее значительных его форм. В исторической перспективе классика даже не может быть названа истоком искусства. Но, начиная с эпохи Возрождения, классика античного искусства была взята за образец, к которому необходимо стремиться. Величайшей похвалой художнику со стороны Вазари было замечание, что его произведения неотличимы от античных. Окончательно это мнение закрепилось после появления на свет «Истории искусства древности» (1763) И. Винкельмана ${ }^{1}$. Теперь миф о классичности настоящего искусства стал таким же авторитетным, как сочинения Отцов церкви для христиан. Результатом такого видения было разделение всех периодов искусства на классические (высокие) и неклассические (упаднические). Эпоха Просвещения, наследие которой до сих пор ощущается в нашей культуре, знала о том, что многое в искусстве не может претендовать на классичность и отрицала эти явления. Хофман цитирует Гете: «Что пользы в том, чтобы усмирить чувственное начало, развить

${ }^{1}$ Винкельман И. И. История искусства древности. Малые сочинения. СПб., 2000. 
Культура и искусство 2(14) • 2013

рассудок и возвести на трон разум? Воображение подстерегает нас словно могущественный враг, оно от природы наделено неодолимым стремлением к абсурдному, которое вопреки всей культуре вновь являет прирожденную грубость гримасничающего дикаря посреди самого благопристойного мира»².

Сегодня противопоставления классического и неклассического выражает себя в том числе и в способе организации музейных экспозиций. Истоки этой традиции очевидны. Ведь сама история искусства и все ее законы зародились во второй половине XVI в., как раз в тот момент, когда перед ренессансной культурой встала угроза разрушения. И поскольку система академического воспитания художников, заложенная братьями Карраччи, не смогла по-настоящему воскресить похороненные вместе с титанами Возрождения художественные идеалы, то этот не удавшийся на практике эксперимент по консервированию традиции был перенесен в теоретическую плоскость: родилась наука, критиковавшая художника, если он не следовал за Рафаэлем. Долгое время главной задачей искусствознания, начавшего свое развитие в XVI в., была пропаганда классики и неприятие всего остального как отхода от единственно достойного образца.

Но поскольку из истории европейского искусства мы знаем, что классика - не единственно возможный, а только один из многих вариантов художественной формы, постольку зачастую даже в самом ортодоксальном с точки зрения его классичности искусстве обнаруживаются примеры, когда художественный замысел произведения требует дистанцирования от провозглашенного конкретной эпохой классического идеала. Антиклассические тенденции можно отметить и в творчестве создателей Возрождения, например, у Донателло в знаменитых «Рельефах северной кафедры церкви Сан Лоренцо» во Флоренции (1560-е гг.). Памятник примечателен тем, что рельефы, стиль которых можно было бы назвать экспрессионистическим, сделаны уже после классицизирующей статуи «Давида» (1553) и восходящей к древнеримскому монументу конной «Статуи Гаттамелаты» (1553).

Но если в случае мастера Раннего Ренессанса стиль рельефов объясняется сосуществованием в его творчестве антикизирующей и позднеготической тенденций, то как быть с А. Дюрером, художником немецкого Возрождения, написавшим трактат о правилах прямой перспективы и тем не менее отклонившимся от ее непреложных правил в своем позднем шедевре - «Четырех апостолах» (1526). В диптихе головы двоих апостолов, стоя-

${ }^{2}$ Хофман В. Основы современного искусства. Введение в его символические формы. СПб., 2004, с. 36. щих позади, больше, нежели у стоящих спереди. Вряд ли это противоречие между теорией и творчеством, как пишет П. А. Флоренский, «предуказывалось общею склонностью его к средневековому стилю и средневековым укладом основ его духа, при новом строе мысли»3. Скорее всего, у каждого большого художника не стиль определяет формы его будущего творения, а задачи самого произведения диктуют мастеру те формы, которые он, свободно черпая из многовековой традиции искусства, выбирает или создает сам.

Как можно убедиться, классические периоды в искусстве кратки. После вспышки Ренессанса итальянское искусство XVII в. не может позиционировать себя как целостная в стилевом отношении и тем более классическая эпоха. Формальная история искусства описывает сосуществование классицизма, барокко и реализма как борьбу антагонистических стилей. Эту точку зрения разделяли и отечественные искусствоведы советского периода, видевшие проявление революционных процессов, сдерживаемых силами реакции, даже в искусстве. Сегодня освобожденный от задач пропаганды ученый может увидеть в XVII в. начало формирования основ современной культуры и отнестись к художественным стилям эпохи как к визуальному выражению основных структур ее мышления. Мы попробуем проанализировать природу взаимоотношений классицизма и барокко, «антагонистически» настроенных по отношению друг к другу с точки зрения формальных отношений Вельфлина. Этот опыт уместен при сравнении родственных друг другу хотя бы с точки зрения своего аристократического происхождения «больших» стилей, тогда как голландский реализм и его локальные разновидности вроде искусства братьев Ле Нэн ${ }^{4}$ выражали мировоззрение набиравшего силу третьего сословия 5 .

Живший на "родине искусства», в Италии, Н. Пуссен (1594-1665), величайший французский художник XVII в., считается основателем и теоретиком искусства классицизма. Сам термин происходит от латинского слова «classicus», что в переносном смысле означает образцовый. Руководствуясь высокими идеями

\footnotetext{
3 Флоренский П. А. Собрание сочинений. Т. 1: Статьи по искусству. Париж, 1985, с. 155 .

4 Хотя с французскими мастерами не все так однозначно. Изображая крестьянские сцены, они ориентировались на аристократического заказчика, поэтому вместо нидерландской непосредственности герои Ле Ненов в своем величественном предстоянии перед зрителем во многом напоминают фигуры Пуссена.

5 Для нас важен этот эксперимент, так при сравнении стилей мы будем оперировать категориями формального анализа, который в сочетании с иконологической интерпретацией может привести нас к открытиям.
} 


\section{Эстетика и теория искусства}

долга и общественного блага, идеалами красоты и гармонической соразмерности мира, классицизм XVII в. был ориентирован на выражение вечных и трансцендентных ценностей 6 . Дидактические задачи искусства заставляли его представителей искать опору в идее совершенства божественного творения и в культе античности, которая понималась как «золотой век» человечества. В картинах Пуссена отсутствует элемент случайности. Абсолютно все: геометрическое построение композиции; чистый локальный колорит, построенный на взвешенной системе отношений между основными и дополнительными цветами; точный рисунок, в основе которого лежит прекрасное знание не только натуры, но, прежде всего, античной скульптуры - красоты, уже очищенной искусством от всего бренного и преходящего. Все это средства служили для выражения основной идеи произведения, в котором герой одерживает тяжелейшую победу над собой, над своими страстями. Возвышаясь над собственной природой, человек обуздывает и подчиняет их, выполняя высший долг.

Стилистические принципы противостоявшего классицизму XVII в. барокко не получили системного развития и теоретического обоснования. Как пишет В. Д. Дажина, сама этимология термина запутана и многозначна, замечательным образом выражая существо этого стиля, который во французском толковом словаре 1771 г. ${ }^{7}$ описывается, в том числе, как стиль в живописи или в каком-либо другом виде искусства, в котором нарушаются все правила и все создается лишь по прихоти художника. Не существует ни одного трактата, в котором бы отстаивались художественные идеи и принципы, которыми руководствовались творцы этого стиля. Более того, его носители (как, например, Бернини) считали, что они ничего не изобретают, а лишь, полагаясь на свои талант и мастерство, развивают великие традиции древних. Только отдельные замечания или записанные близкими к художественным кругам людыми высказывания мастеров позволяют выделить новый в художественной теории того времени принцип «артистичности» (artificio) - особого рода творческой способности, позволяющей художнику выйти за пределы устоявшихся правил, «превзойти природу» и приобрести художественную автономию ${ }^{8}$.

\footnotetext{
${ }^{6}$ Здесь и далее частично пересказывается и цитируется текст из рукописи В. Д. Дажиной: Дажина В. Д. Эстетическая мысль барокко // Искусство и архитектура Европы XVII века.

7 Дажина В. Д. Эстетическая мысль барокко. Рукопись (архив автора), с. 10.

8 Дажина пишет, что этим принципом руководствовался римский живописец и архитектор Пьетро да Кортона
}

Однако теоретические построения обоих стилей покоятся на одном и том же основании. Для Рубенса и Пуссена непревзойденным идеалом была античность. Как и для классицизма, для барокко характерен вычурный формальный язык, коорый отличается особым пристрастием к антитезам, сложным метафорам и замысловатым аллегориям. Новое художественное видение, основанное на идее изменчивости мира, его движения во времени и пространстве, нашло выражение в искусстве барокко в повышенном динамизме и экспрессии, контрастности образной системы и в совмещении в одном произведении «высокого» и «низкого», комического и трагического. В искусстве классицизма тот же образ мышления выразил себя в попытке создать произведения, которые хотя бы в искусстве могли представлять идеальный мир, остающийся недостижимым в нашей реальности. С момента своего появления классицизм оказывается искусственным конструктом, отвечающим этическим и эстетическим идеалам избранных интеллектуалов. Придворная культура того времени требовала более звучных раскатов красок и динамичности композиций. Всем этим в полной мере насыщены картины мастеров барокко.

В отношении к реальности, к интерпретации натуры барокко и классицизм ничем не отличаются друг от друга. Создавая чувственно правдивые образы, они не столько повторяют реальность, сколько творят собственную действительность. По сути, оба направления, оба стиля стремятся превзойти данную нам в ощущениях реальность. Выставленные в музеях обычно в разных залах или на противоположных стенах, классицистические и барочные картины вызывают одинаковое по степени глубины недоумение у современного зрителя, как правило не знакомого с особенностями эстетических теорий этих направлений. Монументальные полотна, где кроме героев значительное место в композиции занимает очеловеченное присутствие аллегорий и многозначных символов, построены на тщательном следовании и глубоком изучении натуры. Мастерство и Рубенса, и Пуссена так велико, что тела и пространства, изображенные в их картинах, вызывают ощущение реальности, а в отдельных местах (например, в изображении мифических сатиров) - даже натурализма. Но при этом, мы уверены, оба гения горячо возмутились бы, если бы кто-то осмелился предположить, что своим искусством они всего лишь «копируют природу». Из одного и того же источника (классической античности) художники заимствуют и развивают в своем искусстве два ее важнейших положения.

в трактате «О живописи и скульптуре», написанном совместно с иезуитом Д. Оттонелли. 
Культура и искусство 2(14) • 2013

Говоря словами эстетики Ницше ${ }^{9}$, Пуссен выражает аполлоническое начало греческого искусства, а Рубенс - дионисийское. Эта разнонаправленная в формальном и семантическом отношении сущность греческого искусства окончательно утверждает сомнение в его однозначной «классичности».

Размышляя о путях развития искусства в XVII в., будет уместно обозначить проблему мимесиса в живописи, принципиальную для разговора о современном искусстве. Как свидетельствуют психологи, первое, от чего получает удовольствие человек, перед глазами которого появилась картина, - узнавание, т. е. фиксация знакомых предметов. Главная претензия, высказываемая по отношению к неклассическому и, в частности, к современному искусству незадачливым зрителем - нереалистичность изображения. Устойчивым является общепринятое мнение, которое разделяет классицизирующие и антиклассические периоды искусства по тому принципу, что первые являются человечными, реалистичными и «понятными», а вторые - схоластическими, абстрактными и деструктивными. На самом деле все намного сложнее. И даже говоря о греческой классике, не стоит заблуждаться относительно «первозданной простоты» этого искусства и непреложности его принципа «верности природе». Всем известно, что идеально ровные формы Парфенона скорее «выглядят» таковыми, нежели являются ими на самом деле. Точно так же невозможно отыскать реального мужчину, телосложение которого соответствовало бы канонам Поликлета. Таким образом, классическим является не произведение, точно воспроизводящее природный первообраз, когда на натюрморты садятся птицы или, приветствуя нарисованных, ржут кони и проч., а произведение, способное (и это гениально покажет Рафаэль) средствами искусства создать идеальный образ сущего или сверхсущего первообраза.

И хотя принято считать, что первый признак «настоящего» (т. е. классического) искусства - повторение натуры, в действительности оно противопоставляет себя и обыденной реалистичности. Ни прекрасная греческая статуя эпохи Высокой классики, ни «Давид» Микеланджело не копируют природу в прямом смысле слова. Мастера классического искусства хорошо понимали, в чем разница между человеком и статуей, реальностью и произведением искусства. Даже римляне, осмеливавшиеся передавать до отвратительного правдивый образ человека, всегда сообщают скульптуре статуарность, которая даже при плохом освещении не позволит принять ее за неподвижно стоящего, замершего человека. Классика противостоит не только «романтическому» (в смысле - некласси-

${ }_{9}^{9}$ Ницще Ф. Рождение трагедии из духа музыки. М., 2005. ческому), но и просто реалистическому, и тем более натуралистическому искусству. Безыскусно реалистические произведения искусства XIX в. (например, бидермейера ${ }^{10}$ ) свидетельствуют о потере чувства классического не в меньшей степени, чем эксперименты художников романтизма.

Полностью отвечая духу времени и принимая «человеческий масштаб», искусство бидермейера становится банальным и приземленным. Оно не просто временно отходит, а безвозвратно утрачивает величественность «большого» стиля, производя на свет такие казусы, как портрет «Князя Иоганна I фон Лихтенштейн с семьей в вымышленном зале с фамильными портретами» (1837) кисти А. Йеника. Можно долго перечислять сильные стороны полотна (ясно прочитываемый замысел, точно переданное портретное сходство изображенных на фоне воображаемых руин родового замка членов семейства), но все это величественное зрелище рушится и превращается в карикатуру при взгляде на центральную фигуру композиции, изображающую аллегорию Благодарного Отечества, увенчивающую лавровыми венками князя и его наследника. Комичность скульптурной фигуры состоит в том, что Благодарное Отечество выглядит как еще один член княжеского семейства, только выкрашенный в белый цвет. И если в таких классических жанрах, как историческая картина или парадный портрет, художники бидермейера не могут соперничать со «старыми мастерами», то им нет равных в жанровых сценках, семейных портретах, изображениях парков и интерьеров - во всем том, что ориентировано на внутренний мир маленького человека. На фоне этих прелестных и живых сценок, трогательных детских портретов особенно отчетливо ощущается безвозвратная потеря больших тем искусства. Без подписи в портретах той эпохи трудно разобраться, изобразил художник самодовольного булочника или родовитого князя.

Еще в начале XX в. П. Флоренский писал: «Схема истории искусств и истории просвещения вообще, как известно, начиная с эпохи Возрождения и почти до наших дней, неизменно одна и та же, и притом чрезвычайно простая. В основе ее лежит непоколебимая вера в безусловную ценность, в окончательную завершенность и, так сказать, канонизированность, вознесенность почти в об-

\footnotetext{
10 Начало этого периода связано с работой Венского конгресса и созданием императорами России, Австрии и Пруссии Священного союза (1815), закрепившего новое политическое устройство Европы после Наполеоновских войн, а окончание - с революционными событиями 1848 г. во Франции, Германии и Австрии. В течение зо-летнего периода политической стабильности и национального подъема в государствах, объединенных в политический союз, сформировалось социально-культурное явление, получившее название бидермейер.
} 


\section{Эстетика и теория искусства}

ласть метафизическую, буржуазной цивилизации второй половины XIX века...»" ${ }^{11}$ Действительно, на это время приходится расцвет классицизирующего академического салонного искусства, глазурный блеск которого пытался скрыть признаки его разложения. Однако, несмотря на все попытки удержать в искусстве «большой» стиль, главный академический жанр - историческая картина в то время уже представляла собой эклектичное явление, своего рода иллюстрацию «дней минувших анекдотов», в большей или меньшей степени украшенных изображением обнаженного женского тела. В таком искусстве обыватель находил все, что ему требовалось: иллюстрацию популярного литературного произведения, мастерское изображение натуры и даже морализаторский смысл («Сократ у Аспазии» Н. А. Монсио, 1801; «Христианская мученица времен Диоклетиана в Тибре» И. Делароша, 1853; «Царь Кандавал» Ж.-Л. Жерома, около 1859-1860; «Визит к Эскулапу» Э. Пойнтера, 1880; «Купание придворных дам в XVIII веке» Ф. Фламенга, 1888). Но если потребитель с удовольствием принимал красивое и понятное искусство, под видом воспитания и просвещения обращавшееся к самым низким его инстинктам, то художникам, несогласным с тем, что единственной целью искусства является бесконечное гладкое и скрупулезное изображение школьных мифов и историй, в которых деяния героев на поле боя все более замещались подвигами на ложе любви, а катарсис подменялся эротикой, хотелось обновления искусства.

В эпоху Наполеоновских войн, окончательно разрушивших представление об особой роли европейской аристократии (главного заказчика классицизирующего искусства), во многих странах Европы почти одновременно возникает искусство романтизма, в основе эстетики которого было новое представление о «возвышенном». Центральное место в искусстве (место Бога или великой личности) было занято драматическим событием. Люди, пережившие эпоху Наполеона I, его стремительный взлет и принятие императорской короны, военные походы, сокрушавшие древнейшие европейские династии, и столь же стремительное падение, наглядно убедились, что величие зависит от обстоятельств. В творчестве великого английского пейзажиста У. Тернера это мироощущение нашло свое выражение в полотнах, где грандиозная и вызывающая трепет стихия была противопоставлена бренному существованию человека и вынуждала его на отчаянную и в тоже время обреченную борьбу («Снежная буря. Переход Ганнибала через Альпы»,

\footnotetext{
${ }^{11}$ Флоренский П. А. Обратная перспектива // Флоренский П. А. Столп и утверждение истины / Приложение к журналу «Вопросы философии». М., 1990, с. 56.
}

1812). Новое представление о целях искусства не могло не отразиться и на живописной манере художника; по удивительно меткому выражению одного из многочисленных недоброжелателей, художник изображал не объекты, а среду, в которой они находятся. У Тернера появляются произведения, настолько близкие к различным вариациям современного искусства, что некоторые из них заслуживали бы права называться импрессионистическими, экспрессионистическими и даже абстрактными, если бы понятие беспредметного искусства уже возникло в умах его современников («Бурное море с обломками кораблекрушения / Гибель Амфитриты/. Пожар в море», 1833-1835; акварель «Венеция, дома», 1839; «Восход солнца. Морские чудовища», ок. 1844-1846).

Строго говоря, модернизм не «убивал» классическое искусство: оно медленно вырождалось по мере потери в нем необходимости. Дух классического искусства выветривался и из своих храмов придворных Академий художеств. Его невозможно было заменить только бесконечными повторениями определенного набора правил, следуя которым искусство смогло бы вечно пребывать в формах античности, базирующихся на представлении о соразмерности и гармоничности для греческого искусства и на имперском пафосе - для римского.

Интересное историческое свидетельство происходившей в XIX в. драмы, когда художники делали последние попытки удержать ускользавший дух классичности, - книга «Фридрих Овербек и его картина “Таинство покаяния” ", вышедшая в 1865 г. в Москве с одобрения цензуры ${ }^{12}$. Оставшийся анонимным автор пишет, что после наполеоновского вторжения «лучшие умы того времени, видя безысходность политического положения родины, стали искать утешения и спасения, пролагая себе новые пути в области мысли ${ }^{13}$ », подразумевая под этим выражением перенос внимания с античности к Средним векам. Обращение к последним было вызвано в первую очередь ностальгией о былом политическом величии Германии и представлением о чистоте христианской веры предков, в основе которой лежала идея «без ропота переносить все земные страдания» ${ }^{14}$. Поэтому типичным, продолжает автор книги, для немецких художников был отказ от образования в Академиях художеств и переезд в Рим, на чьей священной земле они пытались найти в искусстве прошлого путь для обновления своего искусства и, чтобы обрести «подлинную»,

\footnotetext{
12 Фридрих Овербек и его картина «Таинство покаяния», принесенная в дар Московскому публичному музею графом В.П. Орловым-Давыдовым. М., 1865.

${ }_{13}$ Там же, с. 3

${ }_{14}$ Там же, c. 4 .
} 
Культура и искусство 2(14) • 2013

«первоначальную» духовность, даже переходили в католичество.

Описывая эти события, автор постоянно говорит о «новом движении умов», «новом воззрении» и «духе романтизма», противостоящем духу академий, которые в начале XIX в. «все находились в глубоком упадке. В них господствовало направление школы Каррачей и Давида, так называемый классицизм, весь исполненный лжи и внутренний пустоты» ${ }^{15}$. Не случайно для программного произведения одного из лидеров назарейцев $\Phi$. Овербека был выбран сюжет «Въезд Христа в Иерусалим». Подобным образом назарейцы мечтали покорить Рим и Европу. Свою первую выставку они назвали «Новонемецкое религиозно-патриотическое искусство» (1819).

Надо отдать должное автору книги: искренне восхищаясь тем новым, что появляется в искусстве Овербека и его последователей, он видит и слабые стороны творческого метода, направленного на воскрешение форм давно минувшего прошлого. Подробно рассказывая о полотне Овербека «Торжество религии в искусствах» ${ }^{16}$, он отмечает, что в картине «нет простого лирического настроения души: целью художника было действовать на зрителя, развивая перед ним ряд богатых содержанием символических идей, поэтому все значение этого важного произведения... ....лежит в идеальном значении композиции, в богатстве мыслей, ею выражаемых» ${ }^{17}$.

Гете критически отнесся к «новорелигиозному» искусству, считая, что подражание несовершенным формам «примитивов» ${ }^{18}$, в картинах которых встречались нарушения перспективы, отходит от классического образца и потому недолговечно. Искусство назарейцев, считал Гете, всего лишь выражает моду на сентиментальное, которая не сможет продолжаться более 40 лет. Значительно более лояльно настроенный автор книги об Овербеке сумел разглядеть истинную причину, не позволившую назарейцам стать устойчивой базой обновления европейского искусства: провозглашенная Овербеком идея небесного происхождения истинного искусства не получила выражения в произведениях художника; вместо того, чтобы выражать «божественный восторг», они избыточностью символических форм и сложных отношений между ними «низводят нас в круг самых холодных размышлений» ${ }^{19}$.

XIX в. вообще будет богат на разнообразные эстетические программы, боровшиеся с «официа-

\footnotetext{
15 Фридрих Овербек и его картина «Таинство покаяния», принесенная в дар Московскому публичному музею графом В.П. Орловым-Давыдовым, с. 5

${ }_{16}$ «Триумф религии в искусстве», 1839-1843, 392х392. Штеделевский институт, Франкфурт-на-Майне.

${ }_{17}^{17}$ Фидрих Овербек и его картина «Таинство покаяния», с. 12.

${ }_{18} \mathrm{~B}$ том числе на итальянское искусство XV в.

19 Фридрих Овербек и его картина «Таинство покаяния», с. 11.
}

льным» искусством с таким же пылом, как впоследствии революционеры будут бороться с европейскими монархиями. Уже с середины XIX в. в Великобритании начался еще более смелый эксперимент по обновлению искусства. Принципиальным моментом тут тоже был отказ от академической традиции. Название братства художников - «прерафаэлиты» - в полной мере выразило их главную идею. Противопоставляя свое искусство салонному академизму, истоки которого они видели в творчестве Рафаэля, художники поставили перед собой задачу добиться правдивого изображения сильных чувств и драматических переживаний. Е. А. Некрасова отмечает, что к середине XIX в. стиль последователей великого мастера Возрождения «основывался на штампах и манерности, равнялся исключению всякой правды» ${ }^{20}$. Как считает Л. Хаусман ${ }^{21}$, члены братства не выступали против Рафаэля как такового: «Рафаэль является конечным выводом - прекрасным и благородным, где отброшено все лишнее с определенной целью - выражения идеального типа человечества, своего рода обожествленного и значительного. И это сформулировано у Рафаэля с непревзойденной изящной величавостью и строгостью стиля. Для этого он обобщил и опустил многое, - например, складки драпировок, сведя их на подчиненную роль, выявляющую лишь крупные формы своих полубогов. Рафаэль сделал это столь великолепно, что триста лет художники, не имеющие своих собственных мыслей в голове, продолжали его копировать» ${ }^{22}$. Поскольку именно такое искусство соответствовало ожиданиям английского общества, реакция на картины прерафаэлитов, где Богоматерь выглядела некрасивой и изможденной плебейкой ${ }^{23}$, была бурной и негативной.

Вступившийся за прерафаэлитов Д. Рескин понял их доктрину слишком буквально. Он выпустил лозунг: «писать, не выбирая ничего и не отбрасывая ничего» 24 . Такая позиция была бы для прерафаэлитов невозможной; следование подобному принципу привело бы «к полной утрате искусства, которое не может существовать без искусственности» 25 . Пытаясь найти выход из кризиса, прерафаэлиты отрицали эпигонов Рафаэля. Они пробовали нащупать дорогу путем синтеза форм кватроченто с сюжета-

${ }^{20}$ Некрасова Е. А. Романтизм в английском искусстве. М., 1975 , c. 150.

${ }^{21}$ Houseman L. Pre-Raphalelitism in Art and Poetry. «Essays by Divers Hands». Transaction of the Royal Society of Litereture, vol. XII, London, 1933

${ }^{22}$ Цит. по: Некрасова Е. А. Романтизм в английском искусстве, с. 150.

${ }^{23}$ Д. Э. Милле. Христос в родительском доме». 1850.

${ }^{24}$ Некрасова E. А. Романтизм в английском искусстве,

c. 150 .

${ }^{25}$ Там же. 


\section{Эстетика и теория искусства}

ми английской поэзии, переданными с непосредственностью обыденности. Но при всей свежести их искусство не смогло стать альтернативой салонному академизму. В конце концов прерафаэлизм превратился в некий этап, который неизбежно должны были проходить в своем творчестве все английские художники. К началу XX в. он полностью израсходовал пыл в изображении высоких и одновременно правдивых чувств и стал стремиться к утонченности, быстро переходившей в декоративность, и растворился в модерне.

Надо отметить, что революционные движения в искусстве XIX в. не случайно совпали с кризисными настроениями времени. Даже неглубокое знакомство с литературой конца XIX в. передает то ощущение упадка, который переживался современниками. И оно было всеобщим. Знаменитый (сегодня - одиозно знаменитый) французский архитектор, реставратор и историк архитектуры Э. Э. Виолле-ле-Дюк (1814-1879) писал: «Героические эпохи остались далеко позади, яркие индивидуальности уходят из памяти, каждый из нас инстинктивно ощущает, что старый мир гибнет, и в преддверии его крушения, которое все предчувствуют, просвещенные умы с лихорадочным упорством пытаются собрать воедино все, что пригодится грядущей цивилизации; пришла пора ничего не упустить в нашем прошлом, потому что чувствуется, как оно ускользает» ${ }^{26}$.

В академическом искусстве главенствующий в строгой иерархии исторический жанр породил новое явление - исторический стиль. Средствами искусства он пытался удержать приметы прошлого, которое на фоне происходивших в культуре метаморфоз (стремительной смены ритма жизни, угасания формировавшихся веками традиций и устоев, научных открытий и смелых гипотез философов и биологов, кровопролитных революций, когда повседневность утрачивала стабильность, а будущее - предсказуемость) становилось единственной устойчивой опорой человечества, неизбежно приобретая ореол «золотого века». Но духовная жизнь человечества никогда не могла ограничиться лишь консервированием традиции, пусть даже самой прекрасной. Мысли о необходимости реформирования искусства посещали многих художников ${ }^{27}$, но традиционно главными новаторами в области формы

\footnotetext{
${ }^{26}$ Из «Краткого исторического очерка» ко 2-му тому «Dictionnaire raisonne du mobilier francais». Цит. по: Лики истории в европейском искусстве 19 века: Каталог к выставке в ГМИИ им. Пушкина. М., 2009, с. 50.

${ }^{27}$ По воспоминаниям М. В. Добужинского, художники круга «Мира искусства» видели в себе таких реформаторов и даже создателей нового искусства. См.: Добужинский M. B. Воспоминания. М., 1987, с. 191-220.
}

и содержания живописи считаются французские импрессионисты. Заложенная в их творчестве рациональная идея увидеть мир безо всякой легенды и мифа, таким, каким он предстает перед человеческим взором, привела к появлению новых форм видения в искусстве. Безыскусную сущность импрессионизма, позже обвиненного в формализме и считающегося первым направлением, указавшим дорогу бесовскому авангарду, высказал еще Дж. Рескин: «Все, что воспринимаешь в мире вокруг себя, предстает перед твоим взором как определенным образом расположенные, различные цветовые пятна разной интенсивности, - восприятие твердых форм есть прерогатива опыта. Мы не видим ничего, кроме плоских цветовых пятен, и лишь опыт помогает нам установить, что черное или серое пятно обозначает темную сторону черного предмета ${ }^{28}$.

В 1914 г. в Москве вышла книга Г. Тастевена «Футуризм (На пути к новому символизму)». Ее автор делает следующий вывод: «В известном смысле можно сказать, что идеи футуризма носятся в воздухе, и что вся наша эпоха под знаком футуризма. Это огромное движение возрождения культурных ценностей, создания нового идеализма и нового приятия мира, идущего на смену разложившемуся позитивизму и теории прогресса, которые уже не соответствуют новым социально-психологическим возможностям нашей современности и великолепному расцвету технико-экономической энергии» ${ }^{29}$. В изобразительном искусстве начала XX в. эти «носящиеся в воздухе» идеи, сформулированные в философии А. Бергсона, нашли свое выражение в движении футуристов, акмеистов, кубофутуристов и всех остальных разновидностей авангарда. Его художники были готовы преподнести миру новые формы по-настоящему современного искусства, готового занять место архаического классицизма академий и салонов.

Таким образом, напрашивается вывод, что классическое в искусстве не есть что-то устойчивое и постоянное. Наоборот, редким эпохам удается на мгновение выхватить из потока жизни и удержать в искусстве тот самый идеал, которым будут бредить последующие поколения. Печальная правда заключается в том, что никакие правила, доктрины и школы не смогут удержать классическое там, где оно уже было утрачено. Именно поэтому к началу XIX в. можно видеть не появление, а возрастание и решительную динамику превращения

\footnotetext{
${ }^{28}$ Хофман В. Основы современного искусства. Введение в его символические формы. СПб., 2004, с. 72.

29 Тастевен $Г$. Футуризм (На пути к новому символизму). С приложением главных футуристских манифестов Маринетти. М., 1914, с. 19-20.
} 
Культура и искусство 2(14) • 2013

классического в академической интерпретации в несовременное и неактуальное. И когда во второй половине XIX в. художникам стало очевидно, что классика окончательно потеряна и попытки реанимировать ее ни к чему не привели, возникла потребность создать нечто противоположное ей, найти новые формы искусства, которые отталкивались бы от ее законов, как от противного. Но рождение современного искусства не столько разрешило проблемы кризиса классического, сколько породило новые.

Говоря о «современном искусстве», часто, чтобы избежать повторения, мы будем использовать понятие «модернизм». В отечественной историографии советского времени этот термин был «ругательным». Несмотря на его «недобрую» репутацию, нам удобно его использовать как раз потому, что под ним всегда подразумевались неклассические формы изобразительного искусства, начиная с импрессионизма, сменившие искусство академическое, ориентированное на формы классической античности и Ренессанса. Таким образом, термин «модернизм» значительно шире, чем, например, «авангард» и даже включает его в себя: «... “современный” означает не некую модерность, которой прилежно служит мода, не последний ее писк..., а особую духовную проблематику... Речь идет не о том, что современное искусство является более недоступным и поэтому более проблематичным, чем искусство прошлых эпох, а о том, что оно превратилось в проблему для себя самого» ${ }^{\circ}$. Термин «современное искусство» имеет долгую историю.Обращение к ней может не только прояснить его содержание, но и выявить основной круг проблем, связанных с категорией «современного» в искусстве.

Вспомним еще раз, что зарождение науки об искусстве в XVI в. было напрямую связано с перипетиями художественного стиля в его отторжении и преодолении прошлого и в движении к искусству настоящего и будущего. Впервые так же серьезно, как сегодня, противопоставление «старого» и «нового» в значении традиционного и современного в разговоре об искусстве появляется в эпоху Возрождения. Младшие современники Микеланджело, Рафаэля, Тициана и, прежде всего, Вазари ${ }^{11}$ остро ощутили грандиозность пережитой их временем реформы, когда искусство ушло от условности образов Средневековья и вернулось к подражанию природе, когда произошло воскрешение эстетического идеала классической античности. И хотя, как отмечает Х. Зедльмайр, и до этого многие направления искусства прошлого

\footnotetext{
${ }^{30}$ Хофман В. Основы современного искусства..., с. 12.

${ }^{31}$ Вазари Д. Жизнеописания наиболее знаменитых живописцев, ваятелей и зодчих: В 5 т. М., 1956-1971.
}

объявляли себя «современными» (например, «еще строители первых готических соборов различали применительно к своему творчеству “орus modernum” и “opus antiquum” » ${ }^{22}$ ), именно Вазари создал отчетливый образ противостояния старого и нового, заложив основы проблематики истории европейского искусства.

Вазари писал, что искусство зародилось в цивилизациях Древнего Востока, расцвело в эпоху Античности и начало клониться к упадку во времена правления императора Константина в IV в. Как представитель ренессансной традиции, он видит упадок в искусстве там, где оно проявляет себя в отвлеченных, абстрактных формах, т. е. не следует природе. Рассуждая о достоинствах художников Возрождения, чтобы избежать путаницы в терминологии, Вазари делает оговорку, что «древним» он будет называть искусство греков и римлян, а «старым» - искусство Средневековья, которое он противопоставляет «новому способу рисования»33. Так, развитие искусства описано им как переход от «греческой манеры» к «новой манере» 34 .

Сам термин «новая манера», которым пользуется Вазари применительно к изобразительному искусству, - вариант распространенного в его время понятия «ars nova» («новое искусство»), связанного с развитием музыки 35 . В современном искусствознании после Панофского ${ }^{36}$ словосочетание «ars nova» понимается более широко и применяется также в области изобразительного искусства, когда речь идет о живописи Северного Возрождения.

B XIX в. новейшие явления в искусстве, противопоставившие себя уже традиции Возрождения и всех разновидностей классицизмов, стали обозначать как «современные», используя семантически однородное слово «модерн». История появления этого термина в области эстетики изложена Ю. Хабермасом $^{37}$. Немецкий исследователь пишет, что впервые понятие «модерн» в контексте противостояния

\footnotetext{
32 Зедльмайр $X$. Революция современного искусства // Зедльмайр X. Утрата Середины. М., 2008, с. 248.

33 Вазари Д. Жизнеописания наиболее знаменитых живописцев, ваятелей и зодчих: В 5 т. Т. 1. М., 1956, с. 155.

34 Там же, с. 166.

35 Ars nova - прогрессивное направление в музыке, возникшее во Франции и Италии в XIV в. Получило название в противовес ars antiqua («старинное искусство») - полифонической музыке феодально-церковного средневековья по трактату «Ars nova» (1320-е гг.), приписываемому Филлипу де Витри. См.: Музыкальная энциклопедия: В 6 т. / Под ред. Ю. В. Келдыш. М., 1973. Т. 1, с. 227.

${ }^{6}$ В предисловии к книге О. Бенеша «Искусство северного Возрождения» В. Н. Гращенков пишет, что Э. Панофский назвал нидерландскую живопись «ars nova» («новое искусство»), чтобы отличить ее от итальянского Ренессанса с его «возрождением античности» (Бенеш О. Искусство Северного Возрождения. М., 1973 / N.Y., 1965/, с. 19).

${ }^{37}$ Хабермас Ю. Философский дискурс о модерне. М., 2003.
} 
современного и классического было использовано в трактате «Querelte des Anciens et des Modernes» ${ }^{38}$ («Спор древних и новых»); его появление свидетельствует о том, что в начале XVIII в. был инициирован процесс смены образца, в качестве которого ранее выступало античное искусство. Хабермас также отметил, что «первым философом, который развил ясное понятие модерна, был Гегель» ${ }^{39}$, использовавший это понятие в историческом контексте для обозначения эпохи: «новое время» есть «время модерна». У Зедльмайра мы читаем, что «уже рококо от своих современников получило наименование "style modern"»40, но, как отмечает Хабермас, окончательное закрепление значение термина «современный» - «modern» в области эстетики произошло в середине XIX в.: Ш. Бодлер использует его, противопоставляя в искусстве вечное и классическое современному и актуальному. Хабермас приводит слова Бодлера: «Прекрасное образовано из вечного, неизменного элемента... и из относительного, обусловленного элемента... который представлен определенным периодом времени, модой, духовной жизнью, пристрастием. Без этого второго элемента как некой забавной блестящей глазури, которая делает божественный пирог более удобоваримым, первый элемент был бы для человеческой натуры вредным» ${ }^{41}$. Как критик искусства Бодлер подчеркивает в модернистской живописи аспект «мимолетной, преходящей красоты нынешней, современной жизни», «характер того, что читатель позволил нам обозначить как “модерность” $4^{4}$.

К началу XX в. понимание современного в искусстве как явления, противостоящего прошлому и устаревшему, становится традицией. В русском искусствознании термин «модерн» принимает и сохраняет значение художественного стиля в изобразительном искусстве рубежа XX в. Но даже здесь «модерность» проявляется как новое, как альтернатива историческому стилю, точнее - бесстилью, прикрывавшему греческим ордером или готической декорацией современные конструкции строящихся зданий.

Сегодня вместо термина «модерн» принято также употреблять термин «contemporary art» (буквально с английского: «современное искусство»). Его главный недостаток - сравнительно недавнее появление. Это понятие некорректно применять в разговоре об искусстве рубежа XX в., поэтому мы будем в дальнейшем использовать понятие «модернизм». Оно достаточно широко и способ-

\footnotetext{
${ }^{38}$ Там же, с. 13 .

${ }^{39}$ Хабермас Ю. Философский дискурс о модерне, с. 10.

${ }^{40}$ Зедльмайр $X$. Революция современного искусства, с. 247.

${ }^{41}$ Цит. по: Хабермас Ю. Философский дискурс о модерне,

c. 14 .

${ }^{42}$ Там же, с. 14 .
}

но последовательно вобрать в себя самые важные перипетии форм художественного видения, начиная с импрессионизма. Мы привлекаем его для обозначения периода в развитии искусства, который начался в конце XIX в. и продолжается до сих пор. Решая вопрос, какое искусство можно назвать современным и модернистским, мы будем придерживаться традиционной и главенствующей в отечественной науке точки зрения, высказанной еще в 1923 г. Б. Р. Виппером. В статье «Искусство без качества» 43 , посвященной критике как современного искусства, так и искусствознания, ученый делает вывод, что фундаментальные изменения начинаются с импрессионизма. Хофман считает, что импрессионистическое искусство, открывшее восприятию «максимум первозданности и спонтанности», было «существеннейшим аргументом для распредмечивания живописи» 44 . Именно импрессионисты, осуществившие на практике лозунг Дж. Рёскина о «невинности глаза», выступающие за бесформенность и эскизность манеры письма, открыли путь для авангарда, который признан своеобразным эталоном современного искусства.

В связи с тем, что в более поздней (по сравнению с Б. Р. Виппером) искусствоведческой литературе появилась тенденция разделять модернизм и абстракционизм и отличать модернизм от постмодернизма, необходимо сделать несколько замечаний. Хотелось бы дистанцироваться от принятого сегодня понимания искусства авангарда как чего-то отдельного и самостоятельного в модернизме. Наша позиция обусловлена, в частности, намерением посмотреть на феномен современного искусства как на нечто целостное. Поэтому мы не будем четко разграничивать модернизм и авангард, как это делает В. Г. Власов («не следует смешивать модернизм с авангардизмом»45). К авангардному искусству он относит абстракционизм, дадаизм, футуризм, сюрреализм, поп-арт, соц-арт, арт-дизайн, инсталляции, хэппининг, а к модернизму - имажинизм, кубизм, символизм, акмеизм, фовизм, экспрессионизм. Основное различие, по его убеждению, способное провести четкую границу между модернизмом и авангардом, заключается в том, что «модернисты озабочены совершенствованием формы, авангардисты стремятся к тому же, но их более заботит прагматика - успех, ажиотаж, эпатаж публики, быстрый поверхностный эффект» ${ }^{46}$. Такое утверждение са-

\footnotetext{
43 Buпnер Б. Р. Искусство без качества // Среди коллекционеров. М., 1923. Январь-февраль. С. 7-14.

44 Хофман В. Основы современного искусства. Введение в его символические формы, с. 325 .

45 Власов В. Г. Большой энциклопедический словарь изобразительного искусства: В 8 т. Т. 4. СПб., 2001, с. 587.

46 Там же.
} 
Культура и искусство 2(14) • 2013

мо по себе легко поддается критике: стремление к эпатажу свойственно многим художникам, но это качество искусства еще не позволяет говорить, например, о Караваджо как об авангардисте. Власов утверждает, что «авангард был невозможен без скандала, поэтому почти все его достижения находятся вне сферы художественности» ${ }^{47}$, чем в принципе выводит авангард из сферы искусства. C этим утверждением мы не можем согласиться хотя бы потому, что подобное жесткое разграничение модернизма и авангардизма разрушается самой практикой искусства (например, творчеством В. Кандинского, чьи абстрактные работы нисколько не уступают по художественному значению и качеству произведениям его раннего экспрессионистического периода).

Однако самым дискуссионным в обширной проблематике современного искусства является термин «постмодернизм». Он настолько емок и употребляется так широко, что его невозможно считать устоявшимся понятием, некоей константой. Когда разговор о постмодернизме ведется исключительно с точки зрения проблематики изобразительного искусства, чаще всего он трактуется как новый этап современного искусства, на котором авангард утрачивает революционный пафос, прекращается поиск неведомого, становится все более ощутимой рефлексия, происходит утрированная игра с классическим наследием. Но поскольку эти тенденции в современном искусстве отмечались с самого начала (например: «Завтрак на траве» Э. Мане восходит к «Концерту» Джорджоне, «Жена короля» П. Гогена - таитянская «Венера Урбинская», М. Дюшан пририсовал усы Джоконде еще в 1919 г.), постольку любое противопоставление модернизма постмодернизму и желание говорить о нем, как о чем-то принципиально новом, кажется нам преждевременным.

Говоря о многостилевой эпохе искусства, начавшейся в 1870-х гг. и продолжающейся до сих пор, мы будем называть ее «модернистской», основываясь на термине «модернизм», семантическое начало которого исходит от значения «современный». Аргументом в защиту такого свободного объединения разнообразных и подчас противоречивых стилистических тенденций в искусстве обозначенной эпохи служит тот факт, что с момента появления и до сегодняшнего дня модернизм позиционирует себя как альтернатива классического периода. Именно поэтому само существование модернистского искусства в качестве искусства подвергается сомнению. Иногда полностью, чаще - в своих самых крайних антиклассических проявлениях. С позиции традиционной истории ис-

47 Власов В. Г. Большой энциклопедический словарь изобразительного искусства: В 8 т. Т. 4 , с. 587. кусства модернизмом заканчивается великий этап классического искусства. В рамках исследования, цель которого не разъединять, а объединять - показать историю художественного процесса как ряд последовательно сменяющих друг друга стилистических форм, существующих внутри единой и непрекращающейся истории искусства, - мы не видим смысла разделять современное искусство на модернизм и «новый» по отношению к нему постмодернизм. По нашему глубочайшему убеждению, утверждение постмодернизма ${ }^{48}$ свидетельствует о характерном для деятелей модернизма желании поскорее объявить о конце одного явления и начале чего-то еще небывалого.

Намерение современных художников и исследователей объявить о конце модернизма и начале постмодернизма, а в последствии - постпостмодернизма и т. д., угрожает возникновением еще большей путаницы в разговоре о современном искусстве, чем это есть на сегодняшний день. Динамичное развитие и резкие повороты современного искусства могут спровоцировать ощущение, что импрессионизм уже начинает примыкать к «классике». В частности, Зедльмайр пишет: «Было бы произволом все “искусство XX века” называть современным; многие его направления сегодня ни в каком смысле не современны. Современными могут именоваться те направления, которые и сейчас, в 1955 году, сущностно определяют творчество. Это конструктивно-функционалистичное строительство; так называемая абстрактная (абсолютная) живопись и пластика; наконец, сюрреализм» 49 . Приведенная цитата замечательным образом выявляет главную опасность, подстерегающую каждого исследователя современного искусства. Как только объявляется, что на такой-то день такого-то года современными являются именно эти, а не какие-нибудь другие стили и течения модернизма, вы оказываетесь перед необходимостью пересматривать свои выводы каждые пять-десять лет. Единственный выход из этой ситуации - так основательно подойти к изучению модернизма, чтобы, основываясь на результатах исследования, вывести настолько глубинно сущностные выводы относительно его природы, чтобы уже никогда не спутать его с чем-либо еще. То ест, поставить принципиальный вопрос: чем является по существу искусство, именующее себя «современным»; есть ли вообще смысл говорить об «одном определенном» современном искусстве, если с точки зрения художественной формы в нем возможны такие противоположности, как, скажем, абстрактная живопись и фотореализм?

\footnotetext{
$4_{8}$ Это понятие впервые появилось в книге Р. Панвица «Кризис европейской культуры» (1914).

49 Зедльмайр $X$. Революция современного искусства, с. 248.
} 


\section{Эстетика и теория искусства}

Тема общности существа многочисленных и крайне разнообразных в своих формальных проявлениях течений современного искусства волнует каждого исследователя. Любой компендиум, посвященный современности, не может избежать его обсуждения. В книге «Постмодернизм. Искусство второй половины XX - начала XXI века»50, где собраны практически все способы современной художественной практики, Е. А. Андреева, сравнивая модернистский «Черный квадрат» (1915) Малевича с постмодернистским, но тоже квадратным по формату «Первым человеком на Луне» (1987) Э. Уорхола, не столько находит между ними «пять отличий» ${ }^{1}$, сколько делает неизбежный вывод о преемственности постмодернизма и продолжении в нем модернистского взгляда на мир. Исследовательница отмечает, что «между “Квадратом" Малевича и композицией Уорхола есть одно несомненное сходство: недоверие к картине мира, которую каждый может созерцать ежедневно, глядя в окно, смотря по сторонам» ${ }^{2}$. Андреева делает вывод, что «эта “естественная" картина в актуальном искусстве XX века с течением времени исчезает как таковая»; Малевич нарочито отменяет ее своей геометрической «иконой», а Уорхол «мягко подставляет вместо пейзажа за окном вид на телевизионном мониторе»53. Выводы Е. А. Андреевой подтверждают: постмодернизм ничего принципиально не меняет в новой картине мира, сформулированной модернизмом, а любое модернистское искусство по своей сути противоположно и даже противостоит классическому, которое традиционно связывается с «подражанием природе». До сих пор «Черный квадрат» Малевича трактуется как надгробный памятник классического искусства.

Итак, на любом этапе истории искусства, как только возникает тема «современности», это свидетельствует о коренных изменениях, происходящих в нем в данный момент. И если понятия «современное» и «новое», «современное» и «революционное» по отношению к традиции в этом кон- тексте воспринимаются в качестве синонимов, нам ничего не мешает из широкого круга уже зафиксированных в историографии искусствознания и представленных выше определений современного искусства выбрать термин «модернизм» и определить его хронологические границы, начиная с последней четверти XIX в. вплоть до наших дней. Это обусловлено тем, что до настоящего момента мы не видим никаких свидетельств изменения вектора развития изобразительного искусства.

Как мы уже отмечали, термин «модернизм», в котором изначально заложено семантическое значение нового, кажется нам особенно привлекательным потому, что он не связан с каким-либо конкретным направлением в искусстве (как, например, «модерн»). Но не следует забывать, что одновременно в нем заложена и полемика с наследием. «Современное» всегда рассматривается в паре с традиционным; в искусствознании это будет противостоящая пара «модернистское» и «классическое». В этой паре отношения уже давно определились. Главной претензией, предъявляемой к современному искусству, является общее для историков искусства и общественного мнения самых широких кругов убеждение, что оно разрушило искусство классическое. Хофман показывает, что корни такого суждения уходят в эпоху Просвещения. В академических кругах того времени, диктовавших мнение об искусстве всему обществу, утвердилось заблуждение, что «дикие» стадии искусства уже преодолены. Они считали, что «история искусства и история цивилизации развиваются в согласии друг с другом» 54 . И если классическое (согласно своему первоначальному значению «образцовое») всегда понимается как нечто прекрасное, устоявшееся, прошедшее проверку временем, даже вечное, то позиции модернизма более шаткие. Это всегда нечто новое, революционное, непроверенное и потому сомнительное. То, что должно еще доказать право на существование. Да и само существование модернизма в качестве полноправного оппонента классическому искусству остается под вопросом.

\section{Список литературы:}

1. Андреева Е. А. Постмодернизм. Искусство второй половины XX - начала XXI века. СПб., 2007.

2. Вазари Д. Жизнеописания наиболее знаменитых живописцев, ваятелей и зодчих: В 5 т. М., 1956.

3. В Винкельман И. И. История искусства древности. Малые сочинения. СПб., 2000.

4. Виппер Б. Р. Искусство без качества // Среди коллекционеров. 1923. Январь- февраль. С. 7-14.

5. Власов В. Г. Большой энциклопедический словарь изобразительного искусства: В 8 т. СПб., 2001.

\footnotetext{
${ }^{50}$ Андреева Е. А. Постмодернизм. Искусство второй половины XX - начала XXI века. СПб., 2007.

${ }^{51}$ Так называется раздел Введения.

${ }^{52}$ Андреева Е. А. Постмодернизм..., с. 8-9.

53 Там же, с. 9.
}

${ }^{54}$ Хофман В. Основы современного искусства. Введение в его символические формы, с. 35 . 


\section{Культура и искусство 2(14) • 2013}

6. Гегель Г. В. Ф. Эстетика: В 4 Т. М., 1968-1973.

7. Зедльмайр Х. Революция современного искусства в кн. Утрата Середины. М., 2008.

8. $\quad$ Некрасова Е. А. Романтизм в английском искусстве. М., 1975.

9. $\quad$ Ницше Ф. Рождение трагедии из духа музыки. М., 2005.

10. Лики истории в европейском искусстве 19 века: Каталог к выставке в ГМИИ им. А. С. Пушкина. М., 2009.

11. Тастевен Г. Футуризм (На пути к новому символизму). С приложением главных футуристских манифестов Маринетти. М., 1914.

12. Хабермас Ю. Философский дискурс о модерне М., 2003.

13. Хофман В. Основы современного искусства. Введение в его символические формы. СПб., 2004.

14. Флоренский П. А. Обратная перспектива // Флоренский П. А. Столп и утверждение истины / Приложение к журналу «Вопросы философии». М., 1990.

15. Фридрих Овербек и его картина «Таинство покаяния», принесенная в дар Московскому публичному музею графом В. П. Орловым-Давыдовым. М., 1865.

\section{References (transliteration):}

1. Andreeva E. A. Postmodernizm. Iskusstvo vtoroy poloviny KhKh - nachala KhKhI veka. SPb., 2007.

2. Vazari D. Zhizneopisaniya naibolee znamenitykh zhivopistsev, vayateley i zodchikh. V 5 t. M., 1956.

3. Vinkel'man I. I. Istoriya iskusstva drevnosti. Malye sochineniya. SPb., 2000.

4. Vipper B. R. Iskusstvo bez kachestva // Sredi kollektsionerov. Yanv.-Fev. M., 1923. S. 7-14.

5. Vlasov V. G. Bol'shoy entsiklopedicheskiy slovar' izobrazitel'nogo iskusstva: V 8 t. SPb., 2001.

6. Gegel' G. V. F. Estetika: V 4 T. M., 1968-1973.

7. Zedl'mayr Kh. Revolyutsiya sovremennogo iskusstva v kn. Utrata Serediny. M., 2008.

8. Nekrasova E. A. Romantizm v angliyskom iskusstve. M., 1975.

9. $\quad$ Nitsshe F. Rozhdenie tragedii iz dukha muzyki. M., 2005.

10. Liki istorii v evropeyskom iskusstve 19 veka. Katalog k vystavke v GMII im. Pushkina. M., 2009.

11. Tasteven G. Futurizm (Na puti k novomu simvolizmu). S prilozheniem glavnykh futuristskikh manifestov Marinetti. M., 1914.

12. Khabermas Yu. Filosofskiy diskurs o moderne M.: Ves' mir, 2003.

13. Khofman V. Osnovy sovremennogo iskusstva. Vvedenie v ego simvolicheskie formy. SPb., 2004.

14. Florenskiy P.A. Obratnaya perspektiva // Stolp i utverzhdenie istiny / Prilozhenie k zhurnalu «Voprosy filosofii». M., 1990.

15. Fridrikh Overbek i ego kartina «Tainstvo pokayaniya», prinesennaya v dar Moskovskomu publichnomu muzeyu grafom V.P. Orlovym-Davydovym. M., 1865. 